\title{
ANTIMICROBIAL SUSCEPTIBILITY OF RUMINAL STRAINS OF BUTYRIVIBRIO FIBRISOLVENS
}

\section{MAROUNEK and O. G. SAVKA *}

Institute of Animal Physiology and Genetics, Czech Academy of Sciences, 10400 Prague 10-Uhríněves, * Present Address: Institute of Animal Physiology and Biochemistry, Ukrainian Agricultural Academy, 290034 Lvov

\section{Received June 27, 1994}

\begin{abstract}
Marounek M., O. G. Savka: Antimicrobial Susceptibility of Ruminal Strains of Butyrivibrio fibrisolvens. Acta vet. Brno, 63, 1994: 129-132.

The susceptibility of five ruminal strains of Butyrivibrio fibrisolvens to 23 antimicrobial compounds was examined to evaluate effects of antimicrobials on this bacterium. All strains were very sensitive to ionophores and inhibitors of protein synthesis, except for aureomycin. On the contrary, butyrivibrios were relatively insensitive to inhibitors of carbohydrate metabolism and uncouplers. The strains studied displayed considerable variation in sensitivity to salinomycin, aureomycin and bacitracin. The substrate used to support the bacterial growth (glucose or xylose) influenced the susceptibility of isolates to antimicrobial agents. In one third of the measurements inhibitory concentrations of antimicrobial compounds were lower with xylose-grown than with glucose-grown cells. Different response of xylose-grown cultures to antimicrobials may reflect lower energy supply from fermentation of xylose which was metabolized more slowly and with lower biosynthetic efficiency.
\end{abstract}

Rumen, Butyrivibrio fibrisolvens, antimicrobial susceptibility

Butyrivibrio fibrisolvens is a butyrate-forming anaerobic bacterium, which stains gram-negatively, but which has a thin gram-positive cell wall (Hold e m an et al. 1984). Individual strains that have been isolated from the rumen or various anaerobic habitats can ferment cellulose, xylan, starch, pectin and other plant cell components. In the rumen, $B$. fibrisolvens belongs to the most common bacteria in animals fed widely different diets (De h or it y and G r u b 1977; V an Gyls wyk and Murphy 1993). The purpose of this study was (i) to examine the susceptibility of $B$. fibrisolvens to antimicrobial compounds, and (ii) to compare glucose- and xylose-grown cultures in this respect. In separate experiments the parameters of growth of butyrivibrios on glucose and xylose were measured. Most of antimicrobials tested are common growth promoters or drugs effective in prophylaxis and treatment of various animal diseases.

Previous studies have shown that $B$. fibrisolvens is senstitive to ionophores (De $\mathrm{n} n$ is et al. $1981 ; \mathrm{Nag}$ a r a j a and T ay lor 1987) and antibiotics that interferre with cell wall synthesis (He s pell et al. 1993). Antibiotics susceptibility data may be helpful in assessing phenotypic diversity of $B$. fibrisolvens strains, and also for evaluation of consequences of interactions of antimicrobials with a functionally important rumen bacterium.

\section{Materials and Methods}

B. fibrisolvens, type strain ATCC 19171 was obtained from the American Type Culture Collection. Strain 86 was a gift from the culture collection of the Hannah Research Institute, Ayr, Scotland. Strain X1 was isolated from the rumen fluid of a sheep at this Institute. Strains CE51 and X2D62 were supplied from the National Chemical Research Laboratory, Pretoria, South Africa. Strains were maintained in $20 \%(\mathrm{v} / \mathrm{v})$ glycerol at $-20^{\circ} \mathrm{C}$.

Bacteria were grown on a vitamin-mineral medium, supplemented with $0.1 \%$ yeast extract, $0.1 \%$ enzymatic hydrolysate of casein and 10\% rumen fluid (M a ro u nek et al. 1993). The medium was prepared anaerobically and reduced by $0.025 \%$ cysteine. $\mathrm{HCl}$ and $0.025 \% \mathrm{Na}_{2} \mathrm{~S}_{2} 9 \mathrm{H}_{2} \mathrm{O}$. Glucose or xylose were added at $4 \mathrm{~g} / \mathrm{l}$ (final conc.). The medium was sterilized by autoclaving at $110^{\circ} \mathrm{C}$. Parameters of growth on glucose and xylose were followed in batch cultures at pH 6.5 and $39^{\circ} \mathrm{C}$ in $\mathrm{O}_{2}$-free $\mathrm{CO}_{2}$ atmosphere. Two LF2 fermentors (ČSAV Workshop, Prague) were used. The growth was monitored turbidimetrically as optical density at $640 \mathrm{~nm}$. Incubation was completed after reaching the stationary phase. The cell dry weight was determined after centrifugation of the culture, washing with rinsing solutions and drying at $105^{\circ} \mathrm{C}$ overnight.

The following antimicrobial compound were used: lasalocid (Hoffmann La Roche, Basel, Switzerland), monensin, narasin, avilamycin, tylosin (Eli Lilly \& Co., Indianapolis, USA), salinomycin (Hoechst, Frankfurt, Germany), aureomycin, furazolidone, olaquindox (Farmaceutical Works, Prague, Czech Republic), avoparcin and maduramicin (Cyanamid, Wayne, USA), virginiamycin (Smith Kline Beecham, Genval, Belgium), pentachlorophenol, iodoacete and dicyclohexylcarbodiimide(Fluka, Buchs, Switzerland), bacitracin, lincomycin, spiramycin and dimethylamiloride (Sigma, St. Louis, USA), nitrovin, picric acid and dinitrophenol (Lachema Brno, Czech Republic). Aureomycin was dissolved in methylcellosolve, avoparcin, lincomycin and iodoacetate in water, furazolidone, nitrovin, olaquindox, picric acid and dinitrophenol in dimethylsulphoxide. Other antimicrobials were dissolved in ethanol. Solutions were sterilized by filtration through autoclaved asbestos filtering films and added to sterile media containing glucose or xylose to obtain concentrations from 0.01 to 50 $\mu \mathrm{g} / \mathrm{ml}$. A control contained an equivalent amount of a solvent. Inoculated cultures were incubated in triplicate at $39^{\circ} \mathrm{C}$ for 
$40 \mathrm{~h}$. The minimum inhibitory concentration (MIC) was the lowest concentration of antimicrobial compound which prevented visible growth of butyrivibrios. The determination of MIC was replicated twice for each strain.

\section{Results}

The average time of growth, i. e. the time interval between the inoculation and substrate depletion varied between $5.2-14.5 \mathrm{~h}$ and $8.5-15.7 \mathrm{~h}$ in glucose- and xylose-grown cultures of $B$. fibrisolvens strains, resp. (Table 1). The average production of cell dry matter in these strains ranged from 920 to $1140 \mathrm{mg} / \mathrm{l}$ and from 724 to $854 \mathrm{mg} / \mathrm{l}$ in glucose- and xylose-grown cultures, resp. Table 1 presents averages of three incubations. The susceptibility of

Table 1

Time of growth and production of cell dry matter in cultures of $B$. fibrisolvens on glucose and xylose

\begin{tabular}{|c|c|c|c|}
\hline Strain & $\begin{array}{l}\text { Carbon } \\
\text { source }\end{array}$ & $\begin{array}{l}\text { Time of } \\
\text { growth }\end{array}$ & $\begin{array}{c}\text { Cell dry } \\
\text { matter } \\
(\mathrm{mg} / 1)\end{array}$ \\
\hline ATCC 19171 & $\begin{array}{l}\text { Glucose } \\
\text { Xylose }\end{array}$ & $\begin{array}{c}8.53 \pm 0.71 \\
13.72 \pm 2.04 *\end{array}$ & $\begin{array}{l}1140 \pm 11 \\
854 \pm 106 *\end{array}$ \\
\hline 86 & $\begin{array}{l}\text { Glucose } \\
\text { Xylose }\end{array}$ & $\begin{array}{l}7.14 \pm 0.55 \\
8.83 \pm 0.76\end{array}$ & $\begin{array}{l}981 \pm 75 \\
748 \pm 58^{*}\end{array}$ \\
\hline $\mathrm{X} 1$ & $\begin{array}{l}\text { Glucose } \\
\text { Xylose }\end{array}$ & $\begin{array}{l}5.17 \pm 0.76 \\
8.50 \pm 0.50^{*}\end{array}$ & $\begin{array}{l}935 \pm 65 \\
832 \pm 29\end{array}$ \\
\hline CE 51 & $\begin{array}{l}\text { Glucose } \\
\text { Xylose }\end{array}$ & $\begin{array}{c}5.94 \pm 0.95 \\
14.56 \pm 3.36^{*}\end{array}$ & $\begin{array}{l}920 \pm 40 \\
842 \pm 32\end{array}$ \\
\hline X2D62 & $\begin{array}{l}\text { Glucose } \\
\text { Xylose }\end{array}$ & $\begin{array}{l}14.50 \pm 0.87 \\
15.67 \pm 2.57\end{array}$ & $\begin{array}{l}951 \pm 54 \\
724 \pm 29\end{array}$ \\
\hline
\end{tabular}

Means of three incubations \pm SD

* Significantly different from the corresponding glucose value at $\mathrm{P}<0.05$

Table 2

Minimum inhibitory concentrations ${ }^{2}$ of selected antimicrobial compounds against $B$. fibrisolvens strains grown on glucose

\begin{tabular}{|c|c|c|c|c|c|}
\hline \multirow{2}{*}{$\begin{array}{l}\text { Antimicrobial } \\
\text { compound }^{\mathrm{b}}\end{array}$} & \multicolumn{5}{|c|}{ Strain } \\
\hline & ATCC 19171 & 86 & $\mathbf{X} 1$ & CE 51 & X2D62 \\
\hline \multicolumn{6}{|l|}{ Ionophores: } \\
\hline Lasalocid & $0.40 / 0.40$ & $0.40 / 0.40$ & $0.40 / 0.40$ & $0.20 / 0.20$ & $0.40 / 0.10$ \\
\hline Maduramicin & $0.30 / 0.05$ & $0.05 / 0.02$ & $0.15 / 0.03$ & $0.15 / 0.06$ & $0.04 / 0.04$ \\
\hline Monensin & $0.02 / 0.01$ & $0.02 / 0.01$ & $0.02 / 0.01$ & $0.10 / 0.10$ & $0.15 / 0.05$ \\
\hline Narasin & $0.15 / 0.05$ & $0.15 / 0.15$ & $0.15 / 0.15$ & $0.20 / 0.10$ & $0.05 / 0.02$ \\
\hline Salinomycin & $0.40 / 0.40$ & $0.10 / 0.02$ & $0.15 / 0.15$ & $1 / 0.30$ & $0.10 / 0.10$ \\
\hline \multicolumn{6}{|c|}{ Nonionophore antimicrobials: } \\
\hline Aureomycin & $1 / 1$ & $25 / 10$ & $25 / 25$ & $25 / 25$ & $\mathbf{R} / \mathbf{R}$ \\
\hline Avilamycin & $10 / 2$ & $2 / 1$ & $5 / 2$ & $10 / 5$ & $10 / 10$ \\
\hline Avoparcin & $2 / 1$ & $5 / 1.5$ & $1 / 1$ & $5 / 5$ & $1.5 / 1.5$ \\
\hline Bacitracin & $0.15 / 0.1$ & $3 / 3$ & $3 / 3$ & $1 / 1$ & $20 / 15$ \\
\hline Furazolidone & $50 / 50$ & $\mathbf{R} / \mathbf{R}$ & $50 / 50$ & $\mathbf{R} / \mathbf{R}$ & $\mathrm{R} / 25$ \\
\hline Lincomycin & $1 / 1$ & $0.50 / 0.50$ & $1 / 0.50$ & $1 / 1$ & $1 / 1$ \\
\hline Nitrovin & $10 / 10$ & $5 / 5$ & $25 / 25$ & $30 / 30$ & $25 / 25$ \\
\hline Olaquindox & $2.5 / 2.5$ & $6 / 6$ & $5 / 5$ & $10 / 10$ & $6 / 6$ \\
\hline Spiramycin & $0.10 / 0.10$ & $0.05 / 0.05$ & $0.05 / 0.02$ & $0.10 / 0.10$ & $0.10 / 0.10$ \\
\hline Tylosin & $0.01 / 0.01$ & $0.01 / 0.01$ & $0.02 / 0.01$ & $0.05 / 0.05$ & $0.01 / 0.01$ \\
\hline Virginiamycin & $6 / 6$ & $2.5 / 2.5$ & $2.5 / 1$ & $2.5 / 1$ & $6 / 6$ \\
\hline \multicolumn{6}{|c|}{ Uncouplers and inhibitors: } \\
\hline Chlorpromazin & $50 / 50$ & $25 / 25$ & $25 / 25$ & $\mathbf{R} / \mathbf{R}$ & $30 / 30$ \\
\hline Dinitrophenol $^{\mathrm{c}}$ & $\mathrm{R} / 50$ & $R / R$ & $\mathrm{R} / \mathrm{R}$ & $\mathbf{R} / \mathbf{R}$ & $\mathbf{R} / \mathbf{R}$ \\
\hline Iodoacetate & $\mathrm{R} / \mathrm{R}$ & $50 / 25$ & $R / 25$ & $\mathbf{R} / \mathbf{R}$ & $15 / 15$ \\
\hline Pentachlorophenol & $R / R$ & $50 / 50$ & $50 / 25$ & $50 / 50$ & $50 / 50$ \\
\hline Picric acid & $50 / 50$ & $\mathrm{R} / 50$ & $50 / 25$ & $R / R$ & $\mathrm{R} / 25$ \\
\hline
\end{tabular}

${ }^{a}$ MIC (ug/ml): Glucose/xylose values

bAll strains were resistant to dicyclohexylcarbodiimide and dimethylamiloride

$\mathrm{c}_{2,4}$-dinitrophenol. All strains were resistant to 2,6 - dinitrophenol R, Resistant (MIC $>50 \mathrm{ug} / \mathrm{ml}$ ) 
B. fibrisolvens to antimicrobial compounds is shown in Table 2. The strains studied were very sensitive to ionophores, spiramycin and tylosin. On the other hand, they were more or less resistant to furazolidone, chlorpromazin, dicyclohexylcarbodiimide, dinitrophenol, pentachlorophenol, picric acid and dimetylamiloride. Table 2 presents both MICs found in glucose-grown cultures and MICs found in xylose-grown cultures.

\section{Discussion}

Several authors examined the susceptibility of $B$. fibrisolvens to ionophores (De $\mathrm{n} n$ is et al. 1981; $\mathrm{Nag}$ a raja and $\mathrm{T}$ a y lor 1987), non-ionophore antimicrobial feed additives (El Akkad and Hobson 1966; Wang et al. 1969; S te wart et al. 1983; Nagaraja and T a y lor 1987) and some uncouplers and inhibitors (D a w s on et al. 1979; Y ok oy a m a et al. 1988). In this study the minimum inhibitory concentrations of ionophores (lasalocid, maduramicin, monensin, narasin, salinomycin), inhibitors of protein synthesis (aureomycin, lincomycin, spiramycin, tylosin, virginiamycin), cell wall synthesis (avoparcin, bacitracin), carbohydrate metabolism (furazolidone, iodoacetate, nitrovin) and uncouplers (dicyclohexylcarbodiimide, dinitrophenol, picric acid) were determined. Chlorpromazin is an electron transport inhibitor. Pentachlorophenol, which is a widely used biocide, functions as uncoupler and protonophore. Dimethylamiloride is a selective inhibitor of $\mathrm{Na}^{+} / \mathrm{H}^{+}$antiport. All strains tested were sensitive to ionophores and inhibitors of protein synthesis, except aureomycin. On the contrary, they were relatively insensitive to inhibitors of carbohydrate metabolism and uncouplers. Failure of uncouplers to inhibit growth of butyrivibrios indicates the unimportance of electron transport phosphorylation or the impermeability of the cell wall to these compounds. There was a considerable strain-to-strain variation, esp. as far as the susceptibility to salinomycin, aureomycin and bacitracin is concerned.

It is worth noting that MICs found in cultures grown on xylose were often lower than in cultures grown on glucose (in about one third of measurements). These differences probably reflect lower energy gain (per unit of time) in growth on xylose, which was metabolized more slowly than glucose in all strains examined. In the author's opinion, bacterial cells damaged by antimicrobial compounds are able to equilibrate energy-consuming and energy-producing processes to some extent, provided that the energy supply is sufficient. The differences between MICs on glucose and xylose were most frequent in the ionophore group of antimicrobials, which comprises of compounds influencing directly the energy balance of cells.

\section{Citlivost a resistence bachorových kmenů Butyrivibrio fibrisolvens vưči antimikrobiálním sloučeninám}

Zjištovali jsme citlivost pěti kmenů bakterie Butyrivibrio fibrisolvens vůči 23 látkám s antimikrobiálním účinkem. K pokusům byly použity antimikrobiální sloučeniny, které jsou krmnými aditivy, léčivy, event. látkami se specifickým mechanismem účinku. Všechny zkousené kmeny byly citlivé k ionoforům a inhibitorům proteosyntézy, vyjma aureomycinu. Naopak, butyrivibria byla málo citlivá $\mathrm{k}$ inhibitorům metabolismu sacharidů a látkám rozpojujícím fosforylaci a transport elektronů. Růstová odpověd na přítomnost salinomycinu, aureomycinu a bacitracinu byla značně variabilní. Účinek antimikrobiálních látek byl ovlivněn substrátem kultur (glukosa či xylosa). Inhibiční koncentrace byly často (cca v 1/3 měření) nižši při růstu butyrivibrií na xylose, ve srovnání s glukosou. Zjištěný rozdíl je zřejmě způsoben nižším ziskem energie při fermentaci xylosy, která byla fermentována pomaleji a s nižší biosyntetickou účinností. 


\section{Чувствитөльность и рөзистөнтность рубцовых штаммов Butyrivibrio fibrisolvens к антимикробиальным соединениям}

Изучали чувствительность пяти штаммов бактерии Butyrivibria fibrisolvensк 23-м соединениям с антимикробиальным действием. В эксперименте были использованы антимикробиальные соединения, которые являются кормовыми дебавками, лекарствами или вещесрвами со специфическим механизмом действия. Все штаммы, которые мы изучали были чувствительны кионофорам и ингибиторам противосинтеза, кроме аурэомицина. Наоборот, все B. fibrisolvens были мало чувствительны к ингибиторам метаболизма сахаров и к соединениям, которые россоединяют фосфориляцию и транспорт электронов. Рост в присутствии аурэомицина и бацитрацина был вириабильным. Субстрат культур (глюкозы или ксилозы) влиял на действие антимикробиальных соединений. Ингибирующая концентрация была часто более низкой (в 1/3 части определений), когда субстратом была ксилоза (по сравнению с глюкозой). Вероятно, на наш взгляд, причиной этого была более низкая продукция энергии ксилозы, ферментация которой проходит более медленно и с более низкой биосинтетической зффективностью.

\section{References}

DAWSON, K. A.-PREZIOSI, M. C.-CALDWELL, D. R.: Some effects of uncouplers and inhibitors on growth and electron transport in rumen bacteria. J. Bacteriol. 139, 1979: 384-392.

DEHORITY, B. A.-GRUBB, J. A.: Characterization of predominant bacteria occurring in the rumen of goats (Carpa hircus). Appl. Environ. Microbiol. 33, 1977: 1030-1036.

DENNIS, S. M.-NAGARAJA, T. G.-BARTLEY, E. E.: Effect of lasalocid or monensin on lactate-producing orusing rumen bacteria. J. Anim. Sci. 52, 1981: 418-426.

EL AKKAD, I.-HOBSON, P. N.: Effect of antibiotics on some rumen and intestinal bacteria. Nature 209, 1966: 1046-1047.

HESPELL, R. B.-KATO, K.-COSTERTON, J. W.: Characterization of the cell wall of Butyrivibrio species. Can. J. Microbiol. 39, 1993: 912-921.

HOLDEMAN, L. V.-KELLEY, R. W.-MOORE, W. E. C.: Anaerobic gram-negative straight, curved and helical rods. In: Krieg NR \& Holt JG (Eds) Bergey's Manual of Systematic Bacteriology, Vol. 1 (pp 602-662). The Williams \& Wilkins, Baltimore, USA.

MAROUNEK, M.-PETR,O. -SIMƯNEK, J.: Monensin has no effect on growth and metabolism of Megasphaera elsdenii. Folia Microbiol. 38, 1993: 383-386.

NAGARAJA, T. G.-TAYLOR, M. B.: Susceptibility and resistance of ruminal bacteria to antimicrobial feed additives. Appl. Environ. Mirobiol. 53, 1987: 1620-1625.

STEWART, C. S.-CROSSLEY, M. V.-GARROW, S. H.: The effect of avoparcin on laboratory cultures of rumen bacteria. Eur. J. Appl. Microbiol. 17, 1983: 292-297.

VAN GYLSWYK, N. O.-MURPHY, M.: Some aspects of the rumen microbiology of lactating cows fed diets that differed in terms of PBV (protein balance in the rumen). Swedish J. Agric. Res. 23, 1993: 21-28.

WANG, C.-L.-BALDWIN, B. B.-FULGHUM, R. S.-WILLIAMS, P. P.: Quantitative antibiotic sensitivities of ruminal bacteria. Appl. Microbiol. 18, 1969: 677-679.

YOKOYAMA, M. T.-JOHNSON, K. A.-GIERZAK, J.: Sensitivity of ruminal microorganisms to pentachlorophenol. Appl. Environ. Microbiol. 54, 1988: 2619-2624. 